\title{
DISKRIMINASI YANG DIALAMI ORANG DENGAN HIV/AIDS (ODHA) DAMPINGAN YAYASAN SEHAT PANGHURIPAN SUKOWATI KABUPATEN SRAGEN
}

\author{
DHIFA IFTINAN MAITSA, \\ Politeknik Kesejahteraan Sosial Bandung, dhifaiftinan.di@gmail.com \\ ADMIRAL NELSON ARITONANG* \\ Politeknik Kesejahteraan Sosial Bandung, nelsonaritonang@yahoo.com \\ HELLY OKCTILIA \\ Politeknik Kesejahteraan Sosial Bandung, helly_ocktilia@yahoo.com \\ Note: *correspondence
}

POLITEKNIK KESEJAHTERAAN SOSIAL BANDUNG

JL. Ir. H. Juanda No. 367 Bandung

\begin{abstract}
s
This research is to determine and understand the discrimination experienced by people living with HIV / AIDS at the Panghuripan Sukowati Health Foundation, Sragen Regency, include: 1) characteristics of the informant, 2) verbal expression, 3) avoidance, 4) exclusion, 5) physical abuse and 6) informant's expectations. The method used in this research is descriptive qualitative. Informants in this study were five (5) people with HIV / AIDS and two (2) foundation manager, the determination of informants is done by using purposive sampling technique. Data collection techniques used were in-depth interviews, observations and documentation studies. Data sources used are primary data sources and secondary data sources.

The results showed that verbal insults received by informants in the form of words and sentences were expressed to denigrate people with HIV/AIDS. Avoidance is done by avoiding or keeping away people with HIV/AIDS. Exclusion is done by removing people with HIV/AIDS from a group by terminating social relations. Furthermore, physical abuse is carried out by hurting, beating or attacking people with HIV/AIDS due to their HIV status. The problem of discrimination against people with HIV/AIDS occurs due to stigma against HIV / AIDS and the lack of community acceptance of people with HIV/AIDS. The proposed program is "Increasing Family and Community Concern for People with HIV / AIDS in Efforts to Decrease Discrimination against PLWHA".
\end{abstract}

Keywords:

Discrimination, people with HIV/AIDS

\begin{abstract}
Abstrak
Penelitian ini bertujuan untuk mengetahui dan memahami perihal diskriminasi yang dialami Orang dengan HIV/AIDS di Yayasan Sehat Panghuripan Sukowati Kabupaten
\end{abstract}


Sragen, mencakup: 1) karakteristik informan, 2) penghinaan verbal, 3) penghindaran, 4) pengucilan, 5) kekerasan fisik dan 6) harapan informan. Metode yang digunakan dalam penelitian ini adalah deskriptif kualitatif. Informan dalam penelitian ini berjumlah lima (5) orang dengan HIV/AIDS dan dua (2) orang pengurus yayasan, dengan penentuan informan dilakukan teknik purposive sampling. Teknik pengumpulan data yang digunakan adalah wawancara mendalam (in-depth interview), observasi (observation) dan studi dokumentasi. Sumber data yang digunakan adalah sumber data primer dan sumber data sekunder.

Hasil penelitian menunjukkan bahwa penghinaan verbal diterima informan berbentuk kata-kata dan kalimat diungkapkan untuk merendahkan ODHA. Penghindaran dilakukan dengan cara menghindari atau menjauhi ODHA. Pengucilan dilakukan dengan cara mengeluarkan ODHA dari suatu kelompok dengan pemutusan hubungan sosial. Selanjutnya, kekerasan fisik dilakukan dengan cara menyakiti, memukul atau menyerang ODHA dikarenakan status HIV yang disandangnya. Permasalahan diskriminasi terhadap ODHA terjadi dikarenakan stigma terhadap penyakit HIV/AIDS dan kurangnya penerimaan masyarakat terhadap ODHA. Program yang diusulkan yaitu "Peningkatan Kepedulian Keluarga dan Masyarakat Terhadap Orang dengan HIV/AIDS (ODHA) dalam Upaya Mengurangi Diskriminasi Terhadap ODHA".

Kata kunci :

Diskriminasi, Orang dengan HIV/AIDS 


\section{PENDAHULUAN}

HIV/AIDS merupakan salah satu penyakit yang mengancam hidup manusia. Saat ini tidak ada negara yang terbebas dari HIV maupun AIDS termasuk Indonesia. Provinsi Jawa Tengah pada tahun 2019 menurut koran digital Tribun Jateng menempati peringkat keempat untuk jumlah kasus HIV/AIDS, dengan jumlah kumulatif sebanyak 41.115 kasus. Berdasarkan data tersebut, penderita HIV lebih banyak didominasi perempuan, sedangkan AIDS didominasi oleh kaum laki-laki.

Dinas Kesehatan Provinsi Jawa Tengah pada tahun 2019 menyatakan bahwa Kabupaten Sragen masuk kedalam zona kuning untuk tingkat penyebaran penyakit HIV/AIDS. Komisi Penanggulangan AIDS (KPA) Sragen menemukan 38 kasus baru HIV/AIDS selama dua bulan yakni April hingga Mei 2019. Sementara jika dihitung sejak Januari hingga Mei 2019, ditemukan ada 91 kasus baru HIV/AIDS. Penambahan kasus HIV/AIDS di Sragen makin mengkhawatirkan. Hasil rilis terbaru dari Komisi Penanggulangan AIDS (KPA)
Kabupaten Sragen, setiap hari rata-rata ditemukan 3 kasus HIV/AIDS di Kabupaten Sragen. Sejak 2000 hingga akhir Mei 2019, total ada 1.097 temuan kasus HIV/AIDS di Sragen. Sebanyak 567 kasus di antaranya merupakan HIV, sementara 530 kasus sisanya AIDS.

Perlakuan diskriminasi terhadap ODHA menurut UNAIDS dalam segala bentuknya dapat dikategorikan sebagai pelanggaran Hak Asasi Manusia (HAM) kepada manusia yang bermartabat dan mempunyai harga diri, sebab hak-hak asasi manusia masih melekat sekalipun pada ODHA. Diskriminasi perlakuan tidak wajar yang diberikan kepada seseorang dan atau sekelompok orang juga didasarkan pada penilaian subjektif. Diskriminasi terhadap ODHA mempunyai hubungan erat dengan stigma terhadap HIV dan AIDS, yakni setigma mendorong terjadinya seseorang melakukan diskriminasi, yang pada akhirnya menyebabkan berbagai pelanggaran HAM terhadap ODHA maupun Orang yang Hidup dengan HIV/AIDS (OHIDHA). Pelarangan melakukan diskriminasi telah tercantum pada 
Undang-undang Nomor 39 Tahun 1999

tentang Hak Asasi Manusia, pada undangundang tersebut dituliskan bahwa setiap orang berhak atas perlindungan hak asasi manusia dan kebebasan dasar tanpa diskriminasi.

Merujuk pada uraian di atas, diskriminasi merupakan tindakan yang melanggar HAM dan dapat mengganggu kehidupan ODHA. Hal tersebut didukung data dari KPA Strategi Nasional Penanggulangan HIV dan AIDS pada tahun 2018 mengatakan bahwa diskriminasi dapat mengganggu kehidupan ODHA dengan mempengaruhi tekanan fisik, psikologi dan kehidupan sosial bahkan depresi. Seperti diketahui bahwa diskriminasi terhadap ODHA merupakan salah satu pelanggaran HAM yang paling mendasar, seperti hak untuk hidup bebas, hak atas privasi, serta hak untuk mendapatkan pelayanan kesehatan dan pendidikan.

Diskriminasi atau discrimination menurut The Oxford Dictionary of English dalam Kementerian Sosial (2005:11) merupakan (1) perlakuan tidak adil atau berprasangka terhadap orang atau benda khususnya karena perbedaan ras, suku, usia, atau jenis kelamin; (2) memahami dan mengenali suatu hal berbeda dari yang lain, membedakan atau menilai kualitas. Dalam psikologi diartikan sebagai kemampuan untuk membedakan stimuli yang beraneka ragam;

(3) dalam elektronika diskriminasi berarti seleksi sinyal yang mempunyai karakteristik khusus seperti misalnya frekuensi atau amplitude dengan menyingkirkan sinyalsinyal lain yang tidak dikehendaki.

Pasal 1 ayat 3 Undang-undang Nomor 39 Tahun 1999 tentang Hak Asasi Manusia, menyebutkan pengertian diskriminasi sebagai berikut :

Diskriminasi adalah setiap pembatasan, pelecehan, atau pengucilan yang langsung atau tak langsung didasarkan pada pembedaan manusia atas dasar agama, suku, ras, etnik, kelompok, golongan, status sosial, status ekonomi, jenis kelamin, bahasa, keyakinan politik, yang berakibat pengurangan, penyimpangan, atau penghapusan, pengakuan, pelaksanaan atau penggunaan hak asasi manusia dan kebebasan dasar dalam kehidupan baik individual maupun kolektif dalam bidang politik, ekonomi, hukum, sosial, budaya, dan aspek kehidupan lainnya

Diskriminasi terdiri dari tindakan atau kelalaian yang berasal dari stigma dan 
diarahkan kepada orang-orang yang

mengalami stigma. Diskriminasi adalah perilaku negatif yang ditujukan kepada orang lain. Menurut Myers (2012) dalam Femita Adelina (2017:3), diskriminasi adalah perilaku yang tidak pada tempatnya kepada satu kelompok dan anggota kelompoknya. Perilaku diskriminasi terkadang bersumber dari sikap yang penuh prasangka.

Sementara itu, Theodorson \& Theodorson dalam Bambang Rustanto (2014) mengatakan bahwa diskriminasi adalah perlakuan yang tidak seimbang terhadap perseorangan, atau kelompok, berdasarkan sesuatu, biasanya bersifat kategorikal, atau atribut-atribut khas, seperti berdasarkan ras, kesukubangsaan, agama, atau keanggotaan kelas-kelas sosial.

Diskriminasi memiliki beberapa bentuk yang membedakan secara spesifik tindakan diskriminasi. Newman dalam Miharso (2009) dalam Dian Afriani (2018:2) mengemukakan bahwa, terdapat bentukbentuk diskriminasi yaitu:

1. erbal expression, diskriminasi yang dijalankan dengan cara menghina atau dengan kata-kata.

2. Avoidance, diskriminasi yang dijalankan dengan cara menghindari atau menjauhi seseorang atau kelompok masyarakat tertentu dalam kelompoknya.

3. Exclusion, diskriminasi ini dijalankan dengan cara tidak memasukkan seseorang atau kelompok masyarakat tertentu dalam kelompoknya

4. Physical abuse, diskriminasi yang dijalankan dengan cara menyakiti, memukul atau menyerang

5. Extinction, perlakuan diskriminasi dengan cara membasmi atau melakukan pembunuhan besar-besaran.

HIV

(Human Immunodeficiency

Virus) menurut Lina Favourita Sutiaputri (2014:4) adalah virus yang menyerang sistem kekebalan tubuh manusia yang lamakelamaan akan menyebabkan AIDS. Sedangkan AIDS (Acquired Immuno Deficiency Syndrome) merupakan kumpulan gejala-gejala penyakit karena menurunnya sistem kekebalan tubuh karena virus HIV. 
menyatakan bahwa, HIV merupakan virus yang menyebabkan AIDS, HIV merusak sistem kekebalan tubuh sehingga tubuh mengalami kesulitan untuk melawan jenis bibit penyakit; bakteri, virus, jamur, parasit, dan mikroba lainnya. Sedangkan AIDS merupakan gejala penyakit yang dikarenakan rusaknya sistem kekebalan tubuh yang disebabkan oleh HIV.

Kementerian Sosial RI (2005:12) mengemukakan dalam kaitannya dengan HIV/AIDS, diskriminasi diartikan sebagai perlakuan tidak adil karena mempunyai hubungan langsung dengan HIV/AIDS seperti misalnya status HIV positif atau AIDS maupun hubungan tidak langsung seperti misalnya pasangan, keluarga, sahabat ODHA atau orang yang berurusan dengan ODHA. Diskriminasi HIV/AIDS terjadi saat pikiran negatip menggiring orang, masyarakat atau lembaga mengambil tindakan (tidak bertindak) tidak adil terhadap seseorang atas dasar dugaan atau keyakinan status HIV/AIDS orang tersebut.
DAN AIDS (UNAIDS) (2005:9)

mengemukakan bahwa bentuk diskriminasi terhadap orang yang hidup dengan HIV meliputi: pengucilan, seperti praktik memaksa perempuan untuk kembali ke kerabat mereka setelah didiagnosis HIV-positif, mengikuti gejala awal penyakit, atau setelah pasangan mereka meninggal karena AIDS; menghindari kontak sehari-hari; pelecehan verbal; kekerasan fisik; mendiskreditkan dan menyalahkan secara verbal; gosip; dan penolakan memulasarakan jenazah.

Kementerian Sosial RI (2005) menyatakan bahwa Stigma dan diskriminasi HIV/AIDS dapat terjadi pada tiga tingkat yaitu (1) tingkat Negara-pemerintah, (2) tingkat masyarakat, baik itu lingkungan masyarakat sekitar seperti Rukun Tetangga (RT) dan Rukun Warga (RW) maupun lingkungan masyarakat yang lebih luas seperti kelurahan, desa atau daerah dan (3) tingkat keluarga, baik itu pasangan, orang tua, anak, kakak-adik, maupun lingkungan keluarga besar dan kerabat. 
Yayasan Sehat Panghuripan Sukowati adalah Lembaga Swadaya Masyarakat (LSM) non profit yang memiliki fokus terhadap ODHA. Tujuan dibentuknya yayasan tersebut adalah agar ODHA mendapatkan persamaan hak, mendapatkan akses layanan, kesehatan prima, dukungan yang memadai, serta penghapusan stigma dan diskriminasi.

Berdasarkan latar belakang yang telah diuraikan, peneliti tertarik untuk melakukan penelitian tentang diskriminasi yang dialami Orang dengan HIV/AIDS dampingan Yayasan Sehat Panghuripan Sukowati Kabupaten Sragen. Sehingga dalam penelitian ini, peneliti melakukan penelitian mengenai bentuk-bentuk diskriminasi yang dialami oleh ODHA dampingan Yayasan Sehat Panghuripan Sukowati.

Diskriminasi dalam penelitian ini meliputi empat aspek yaitu penghinaan verbal, penghindaran, pengucilan dan kekerasan fisik. Tujuan penelitian ini adalah untuk mengetahui dan memahami perihal diskriminasi yang dialami Orang dengan HIV/AIDS di Yayasan Sehat Panghuripan Sukowati Kabupaten Sragen.

\section{METODE}

Penelitian ini menggunakan pendekatan kualitatif dengan metode deskriptif guna mengkaji secara mendalam mengenai diskriminasi yang dialami Orang dengan HIV/AIDS (ODHA) dampingan Yayayan Sehat Panghuripan Kabupaten Sragen. Sumber data diperoleh secara purposive. Data primer diperoleh dari data utama yang didapatkan langsung dari orang dengan HIV/AIDS dampingan di Yayasan Sehat Panghuripan Sukowati yang mengalami diskriminasi dan pengurus Yayasan Sehat Panghuripan Sukowati

Sumber data sekunder diperoleh melalui studi dokumentasi tentang: (1) dokumen file profil yayasan untuk mengetahui informasi mengenai sejarah, kegiatan, struktur organisasi, jumlah dampingan dan seluruh informasi yang berkaitan dengan yayasan., (2) data dari Dinas Kesehatan Kabupaten Sragen dan Komisi Penanggulangan AIDS (KPA) Kabupaten Sragen untuk memperoleh data jumlah dan penyebaran HIV di Kabupaten Sragen. Teknik pengumpulan data dilakukan dengan 
wawancara mendalam dan observasi serta studi dokumentasi. Pemeriksaan keabsahan data (Sugiono, 2015:270) dilakukan dengan uji keabsahan data dalam penelitian kualitatif mengandung uji credibilitas (validitas interbal), tranferability (validitas eksternal), dependability (reabilitas) dan confirmability (obyektivitas).

\section{HASIL PENELITIAN}

Hasil penelitian merupakan bagian terpenting dalam setiap kegiatan penelitian. Hasil penelitian yang diperoleh oleh peneliti ini berasal dari hasil wawancara, observasi dan studi dokumentasi kepada informan yaitu dampingan dan pengurus Yayasan Sehat Panghuripan Sukowati. Hasil penelitian dapat dijelaskan sebagai berikut:

\section{Penghinaan Verbal}

Pada aspek penghinaan verbal diketahui bahwa penghinaan verbal dilakukan oleh keluarga, masyarakat dan pelayanan kesehatan. Penghinaan terhadap ODHA berbentuk kata-kata dan kalimat diungkapkan untuk merendahkan ODHA berupa disalahkan mengidap HIV karena perilaku yang menyimpang dimasa lalu; didoakan cepat meninggal; penyebaraan status HIV; mengatakan penyakit HIV merupakan penyakit yang menjijikan; dituduh menjual diri; mengatakan HIV merupakan penyakit yang menular dan harus dijauhi dan mengatakan dandanan ODHA tebal.

Penghinaan verbal terhadap ODHA oleh keluarga, masyarakat dan pelayanan kesehatan dilakukan dengan berbagai alasan. Terdapat dua alasan penghinaan verbal terhadap ODHA dampingan Yayasan Sehat Panghuripan Sukowati yaitu tidak menyukai ODHA dan ODHA dianggap aib masyarakat. Penghinaan yang dilakukan oleh keluarga, masyarakat dan pelayanan kesehatan memberikan dampak terhadap ODHA. Diskriminasi yang dialami oleh ODHA menimbulkan dampak pada aspek psikologis. Dampak psikologis dari penghinaan verbal terhadap informan berupa benci dan marah serta sakit hati.

\section{Penghindaran}

Pada aspek penghindaran diketahui bahwa penghindaran dilakukan oleh keluarga, masyarakat dan pelayanan kesehatan. Penghindaran dilakukan dengan cara 
menghindari atau menjauhi ODHA berupa pemisahan alat makan dan alat mandi; berbicara dengan ODHA dari jauh; tidak disapa saat bertemu ditempat umum; menjauh saat ODHA lewat di depan rumah; tidak mau memakan makanan yang disajikan ODHA; membuang makanan yang diberikan ODHA; tidak mau membeli dagangan ODHA; tidak mau duduk disebelah ODHA; tidak menjawab pertanyaan yang diajukan ODHA dan membuang muka; tidak mau memboncengkan ODHA; tidak mau bersalaman dengan ODHA; serta tidak mau membantu persalinan ODHA.

Terdapat tiga alasan penghindaran terhadap ODHA dampingan Yayasan Sehat Panghuripan Sukowati yaitu tidak nyaman berada di dekat ODHA, kurangnya pengetahuan mengenai HIV/AIDS dan ketakutan berlebihan tertular HIV.

Penghindaran terhadap ODHA menimbulkan dampak psikologis, sosial dan ekonomi terhadap ODHA. Dampak psikologis berupa dendam, sakit hati dan merasa hidupnya sengsara. Dampak sosial berupa ODHA menjadi tertutup dan tidak mau mengikuti kegiatan di masyarakat. Dampak ekonomi berupa tidak ada pemasukan.

\section{Pengucilan}

Pada aspek pengucilan diketahui bahwa pengucilan dilakukan oleh keluarga dan masyarakat. Pengucilan terhadap ODHA berupa tidak memperbolehkan ODHA mengikuti kegiatan di masyarakat; tidak ada yang menjenguk ODHA saat sakit; tidak mau membantu ODHA yang sedang mengalami kesulitan; tidak memperbolehkan anak dengan HIV/AIDS untuk bersekolah; tidak memperbolehkan anak dengan HIV/AIDS bermain dengan teman sebaya; keluarga tidak mau mengurus ODHA; ODHA tidak diperbolehkan pulang kerumah serta pengasingan jenazah ODHA.

Terdapat tiga alasan pengucilan terhadap ODHA dampingan Yayasan Sehat Panghuripan Sukowati yaitu gelisah saat mengetahui dilingkungan terdekatnya terdapat ODHA, tidak mau hidup bersama ODHA dan kurangnya pengetahuan mengenai HIV/AIDS 
Pengucilan memberikan dampak

psikologis dan sosial terhadap ODHA.

Dampak psikologis berupa tidak memiliki semangat hidup, stres dan depresi, sakit hati, dan hidup ODHA menjadi tidak tenang.

Dampak Sosial berupa bertemu KDS dan anak ODHA sulit mendapatkan sekolah

\section{Kekerasan Fisik}

Pada aspek kekerasan fisik diketahui bahwa kekerasan fisik dilakukan oleh keluarga dan masyarakat. Kekerasan fisik dilakukan dengan cara menyakiti, memukul atau menyerang ODHA dikarenakan status HIV yang disandangnya. Berikut merupakan kekerasan fisik yang diterima ODHA: dipukul dan ditendang oleh suami; dilecehkan kakak kandung; serta diusir paksa oleh masyarakat dari tempat tinggalnya.

Terdapat dua alasan ODHA mengalami kekerasan fisik, yaitu rasa amarah yang tidak dapat dikendalikan dan menganggap ODHA merupakan orang yang tidak suci. Dampak yang ditimbulkan dari perlakukan kekerasan fisik terhadap ODHA yaitu dampak psikologis. Dampak psikologis berupa sakit hati, trauma, dan down.

\section{PEMBAHASAN}

Diskriminasi di dalam penelitian ini dilihat dari aspek bentuk diskriminasi yaitu penghinaan verbal, penghindaran, pengucilan dan kekerasan fisik. ODHA mengalami diskriminasi oleh keluarga, masyarakat dan pelayanan kesehatan. Diskriminasi yang dialami oleh ODHA dampingan Yayasan Sehat Panghuripan Sukowati merupakan tindakan yang secara sadar dan sengaja untuk menjauhi dan memusuhi ODHA.

\section{Penghinaan Verbal}

Penghinaan verbal (verbal exspression) menurut Newman dalam Miharso (2009) dalam Dian Afriani (2018:2) merupakan diskriminasi yang dijalankan dengan cara menghina atau dengan kata-kata. Sebuah penelitian di Tanjung Pinang menyebutkan bahwa penghinaan adalah bentuk diskriminasi yang dialami ODHA, masyaraakat memberikan verbal negatif terhadap ODHA dengan menghina dan menyalahkan ODHA atas kelakuan di masa lampau. Penghinaan yang paling umum 
terjadi adalah penyebaran status HIV seseorang. Penggunaan perkataan "HIV" dinilai sangat kasar dan merupakan ungkapan penghinaan bagi ODHA. Penyebarluasan status HIV ODHA dapat membuat ODHA mendapat perlakukan diskriminatif yang lain seperti penghindaran, pengucilan bahkan kekerasan fisik dari orang sekitarnya.

Berdasarkan hasil penelitian di Tanjung Pinang oleh Umi Salamah dari Sekolah Tinggi Kesejahteraan Sosial Bandung tahun 2012, hasil yang diperoleh dari penelitian ini kurang lebih sama. Hasil penelitian menunjukkan bahwa bentuk penghinaan verbal diterima oleh informan dari keluarga, masyarakat maupun pelayanan medis. Penghinaan terhadap ODHA berbentuk kata-kata dan kalimat diungkapkan untuk merendahkan ODHA berupa disalahkan mengidap HIV karena perilaku yang menyimpang dimasa lalu; didoakan cepat meninggal; penyebaraan status HIV; mengatakan penyakit HIV merupakan penyakit yang menjijikan; dituduh menjual diri; mengatakan HIV merupakan penyakit yang menular dan harus dijauhi dan mengatakan dandanan ODHA tebal.

Masyarakat masih memiliki pola pikir bahwa semua orang yang terkena HIV/AIDS adalah orang-orang yang nakal, orang-orang yang sering melanggar aturan Tuhan dan norma sosial yang ada didalam masyarakat. Namun, pada kenyataannya terdapat ODHA yang merupakan korban seperti istri yang tertular dari suaminya dan anak yang tertular dari orang tuanya. Stigma terhadap penyakit HIV/AIDS dan orang yang mengidapnya membuat keluarga dan masyarakat melakukan penghinaan terhadap ODHA.

\section{Penghindaran}

Penghindaran (avoidance) menurut Newman dalam Miharso (2009) dalam Dian Afriani (2018:2) merupakan bentuk diskriminasi yang dijalankan dengan cara menghindari atau menjauhi seseorang atau kelompok masyarakat tertentu dalam kelompoknya. Hasil penelitian menunjukkan bahwa bentuk penghindaran diterima oleh informan dari keluarga maupun masyarakat. Penghindaran dilakukan dengan cara menghindari atau menjauhi ODHA berupa 
pemisahan alat makan dan alat mandi; berbicara dengan ODHA dari jauh; tidak disapa saat bertemu ditempat umum; menjauh saat ODHA lewat di depan rumah; tidak mau memakan makanan yang disajikan ODHA; membuang makanan yang diberikan ODHA; tidak mau membeli dagangan ODHA; tidak mau duduk disebelah ODHA; tidak menjawab pertanyaan yang diajukan ODHA dan membuang muka; tidak mau memboncengkan ODHA; tidak mau bersalaman dengan ODHA; serta tidak mau membantu persalinan ODHA.

Sebuah penelitian di Kediri oleh Achmad Wisnu Maarif dari Universitas Islam Negeri Sunan Kalijaga Yogyakarta tahun 2017 menyebutkan bahwa penghindaran yang dialami oleh ODHA merupakan diskriminasi langsung terhadap ODHA di dalam konteks keluarga berupa pemisahan peralatan makan dan peralatan mandi, sedangkan dalam konteks lingkungan kerja berupa pemberhentian kerja dengan memberikan surat pengunduran diri. Berdasarkan penelitian tersebut, hasil yang didapat kurang lebih sama. ODHA mengalami penghindaran oleh keluarga berupa pemisahan alat makan dan mandi, berbicara dengan ODHA dari jauh dan tidak disapa saat bertemu ditempat umum.

Penghindaran yang dialami ODHA dilakukan dengan dua alasan yaitu tidak nyaman berada di dekat ODHA dan kurangnya pengetahuan mengenai HIV/AIDS dan ketakutan berlebih tertular HIV. Kedua hal tersebut terjadi dikarenakan stigma terhadap penyakit HIV/AIDS yang mudah menular, merupakan penyakit yang memalukan dan belum ada obatnya, serta merupakan hukuman Tuhan terhadap dosa yang ODHA lakukan sehingga masyarakat memiliki ketakutan yang berlebihan terhadap penyakit HIV/AIDS.

\section{Pengucilan}

Pengucilan (exclusion) menurut Newman dalam Miharso (2009) dalam Dian Afriani (2018:2) merupakan diskriminasi yang dijalankan dengan cara tidak memasukkan seseorang atau kelompok masyarakat tertentu dalam kelompoknya. Hasil penelitian menunjukkan bahwa bentuk pengucilan diterima oleh informan dari 
keluarga maupun masyarakat. Pengucilan dilakukan dengan cara mengeluarkan ODHA dari suatu kelompok dengan pemutusan hubungan sosial.

Hasil penelitian diperkuat dengan artikel pada Okezone.com pada tahun 2013 pengucilan terhadap ODHA dilakukan dengan membuang ODHA di pasar daerah Kabupaten Blitar, pembuangan tersebut dilakukan oleh keluarga ODHA. ODHA dibuang di pasar dengan kondisi diare dan terindikasi mengidap TBC. Pengucilan tersebut dilakukan dikarenakan keluarga tidak mau hidup dan mengurus ODHA yang sakitsakitan. Sedangkan pada artikel Jawa Pos menyebutkan bahwa pengucilan tidak hanya terjadi kepada ODHA yang masih hidup namun juga kepada ODHA yang sudah meninggal. Pada artikel tersebut disebutkan warga Desa Jurangjero Kabupaten Sragen enggan memulasarakan jenazah ODHA. Berdasarkan artikel dari Okezone.com dan Jawa Pos, hasil penelitian yang didapatkan pada penelitian ini kurang lebih sama. Pengucilan terhadap ODHA berupa tidak memperbolehkan ODHA mengikuti kegiatan di masyarakat; tidak ada yang menjenguk ODHA saat sakit; tidak mau membantu ODHA yang sedang mengalami kesulitan; tidak memperbolehkan anak dengan HIV/AIDS untuk bersekolah; tidak memperbolehkan anak dengan HIV/AIDS bermain dengan teman sebaya; keluarga tidak mau mengurus ODHA; ODHA tidak diperbolehkan pulang kerumah serta pengasingan jenazah ODHA.

Pengucilan yang dialami ODHA dilakukan dengan tiga alasan yaitu gelisah saat mengetahui dilingkungan terdekatnya terdapat ODHA, tidak mau hidup bersama ODHA dan kurangnya pengetahuan mengenai HIV/AIDS. Ketiga hal tersebut terjadi dikarenakan stigma terhadap ODHA dan penyakit HIV/AIDS sehingga masyarakat melakukan pengucilan terhadap ODHA. Adanya stigma bahwa masyarakat akan menolak keluarga yang didalamnya terdapat anggota keluarga yang memiliki penyakit HIV dan stigma terhadap penyakit HIV/AIDS yang mudah menular dan terhadap ODHA sendiri yang tidak boleh bergaul dengan orang lain karena bukan orang baik. Pengucilan 
akan terus terjadi ketika kurangnya

pengetahuan dari keluarga dan masyarakat. Biasanya pengucilan itu terjadi saat status HIV seseorang tersebar luas dan akan hilang seiring dengan berjalannya waktu dan melihat ODHA itu bisa sembuh dan beraktifitas seperti sedia kala.

\section{Kekerasan Fisik}

Diskriminasi fisik (physical abuse) atau kekerasan fisik menurut Newman dalam Miharso (2009) dalam Dian Afriani (2018:2) merupakan bentuk diskriminasi yang dijalankan dengan cara menyakiti, memukul atau menyerang. Hasil penelitian menunjukkan bahwa bentuk kekerasan diterima oleh informan dari keluarga maupun masyarakat. Kekerasan fisik dilakukan dengan cara menyakiti, memukul atau menyerang ODHA dikarenakan status HIV yang disandangnya. Berikut merupakan kekerasan fisik yang diterima ODHA: dipukul dan ditendang oleh suami; dilecehkan kakak kandung; serta diusir paksa oleh masyarakat dari tempat tinggalnya.

Sebuah penelitian di Tanjung Pinang Umi Salamah dari Sekolah Tinggi
Kesejahteraan Sosial Bandung tahun 2012 menyebutkan bahwa, bentuk diskriminasi yang mengakibatkan kekerasan fisik terhadap ODHA yang paling sering terjadi di masyarakat adalah pengusiran ODHA dari lingkungan tempat tinggal, pengasingan bahkan hingga pembakaran rumah ODHA. Berdasarkan penelitian tersebut, hasil yang didapat kurang lebih sama. ODHA mengalami kekerasan fisik oleh masyarakat dengan adanya pengusiran paksa oleh masyarakat dan pelemparan batu di rumah ODHA.

Kekerasan fisik terjadi terhadap ODHA dikarenakan amarah yang tidak dapat dikendalikan oleh pasangan saat mengetahui pasangannya positif HIV, selain itu terdapat pemikiran yang salah bahwa ODHA merupakan orang yang tidak suci lagi sehingga bebas untuk melakukan apasaja terhadap ODHA. Kekerasan fisik terhadap ODHA dikarenakan status HIVnya merupakan kasus yang sangat jarang terjadi. Hal tersebut dikarenakan saat ini keluarga dan masyarakat memiliki ketakutan yang berlebihan terhadap ODHA sehingga 
membuat orang melihat saja takut apalagi mendekat untuk memukul ODHA.

Setelah diperoleh data deskripsi hasil penelitian tentang diskriminasi yang dialami Orang dengan HIV/AIDS (ODHA) dampingan Yayasan Sehat Panghuripan Sukowati Kabupaten Sragen berdasarkan aspek bentuk diskriminasi penghinaan verbal, penghindaran, pengucilan dan kekerasan fisik, selanjutnya peneliti menganalisis permasalahan yang muncul berdasarkan hasil penelitian yang telah dilakukan.

Analisis masalah merupakan bentuk analisis yang terfokus kepada penarikan akar penyebab masalah. Diskriminasi terhadap ODHA dilihat sebagai masalah yang bersumber dari berbagai penyebab. Penyebab itu kemudian diuraikan menjadi akar permasalahan yang mendasar. Hasil penelitian menyatakan bahwa diskriminasi yang dialami oleh ODHA didasarkan kepada stigma terhadap ODHA. Berikut ini adalah pokok permasalahan yang ditemukan.

1. Adanya stigma terhadap penyakit HIV/AIDS dan ODHA
2. Kurangnya penerimaan masyarakat terhadap ODHA

Setelah melakukan analisis masalah dari hasil penelitian, maka selanjutnya peneliti melakukan analisis kebutuhan berdasarkan masalah yang berkaitan dengan diskriminasi terhadap ODHA. Masalah dan kebutuhan merupakan dua hal yang saling berkaitan satu sama lain. Masalah memerlukan penyelesaian dengan cara pemenuhan kebutuhan. Berdasarkan analisis masalah yang telah dilakukan, diketahui bahwa stigma yang diberikan oleh masyarakat terhadap ODHA menimbulkan permasalahan dan kesalahpahaman antara masyarakat dan ODHA. Berikut akan dibahas mengenai analisis kebutuhan berdasarkan hasil penelitian yang telah dilakukan.

1. Peningkatan pengetahuan keluarga dan masyarakat mengenai HIV/AIDS

2. Peningkatan penerimaan masyarakat terhadap ODHA

Berdasarkan penelitian yang telah dilakukan, terdapat potensi dan sumber kesejahteraan sosial yang dapat dimanfaatkan untuk mengatasi permasalahan terkait diskriminasi 
yang dialami ODHA. Allen Pincus dan Anne

Minahan dalam Dwi Heru Sukoco (1991:38-

39) menyatakan bahwa terdapat sumber-

sumber yang dapat diidentifikasi, yaitu

sumber informal atau alamiah, sumber formal

dan sumber kemasyarakatan. Berikut

merupakan sumber-sumber yang dapat

diakses dan digunakan untuk mengatasi

permasalahan diskriminasi yang dialami

ODHA:

\section{Sistem Sumber Informal atau Alamiah}

Sistem sumber informal merupakan sumber yang dapat memberikan bantuan berupa dukungan emosional, afeksi, nasihat, informasi dan pelayanan-pelayanan konkret. Sumber ini tidak menggunakan prosedur dalam penggunaannya, sifatnya ikhlas, jujur, cinta kasih dan tanpa pamrih. Sumber informal dapat berupa keluarga, teman, tetangga, mitra kerja maupun orang lain yang dapat membantu ODHA

\section{Sistem Sumber Formal}

Sistem sumber formal adalah sistem sumber yang memberikan pelayanan langsung kepada anggotanya dalam suatu organisasi atau asosiasi formal. Sesuai dengan permasalahan diskriminasi yang dialami ODHA dampingan Yayasan Sehat Panghuripan Sukowati Kabupaten Sragen, sistem sumber formal yang dapat diakses yaitu: Organisasi yang diikuti oleh ODHA, seperti KDS Sukowati dan KDS Soloraya, Yayasan Sehat Panghuripan Sukowati Kabupaten Sragen dan Lembaga Swadaya Masyarakat (LSM) yang menangani ODHA di Kabupaten Sragen, yaitu Muslimat NU dan Aisyiyah.

\section{Sistem Sumber Kemasyarakatan}

Sistem sumber kemasyarakatan merupakan sumber berupa lembaga pemerintah maupun swasta yan dapat memberikan bantuan pada masyarakat umum. Sumber yang dapat dikelompokkan dalam sistem sumber kemasyarakatan seperti sekolah, rumah sakit, program-program latihan kerja dan pelayanan kesejahteraan sosial.

\section{KESIMPULAN}

Berdasarkan penelitian yang telah dilakukan, diskriminasi dialami Orang dengan HIV/AIDS (ODHA) berbentuk penghinaan verbal, penghindaran, pengucilan dan kekerasan fisik. Permasalahan diskriminasi 
terhadap ODHA terjadi dikarenakan stigma terhadap penyakit HIV/AIDS dan kurangnya penerimaan masyarakat terhadap ODHA. Kedua hal tersebut membuat permasalahan yang cukup kompleks. Penolakan terhadap ODHA yang hidup di lingkungan sekitar serta kurangnya pengetahuan keluarga dan masyarakat menyebabkan terciptanya stigma terhadap ODHA sehingga menimbulkan tindakan diskriminatif terhadap ODHA. Diskriminasi memberikan dampak psikologis, sosial dan ekonomi terhadap ODHA. Dampak psikologis akibat diskriminasi yang dialami ODHA berupa dendam dan sakit hati dan merasa hidupnya sengsara; dampak sosial berupa ODHA menjadi tertutup, tidak berani keluar rumah dan tidak mau mengikuti kegiatan di masyarakat; dan dampak ekonomi berupa tidak ada pemasukan.

$$
\text { Penanganan diperlukan untuk }
$$

mencegah terulangnya kasus diskriminasi terhadap ODHA dan mencegah konflik yang terjadi karena keharmonisan kehidupan bermasyarakat terganggu. Program yang diusulkan terkait permasalahan yang dialami yaitu program peningkatan kepedulian keluarga dan masyarakat terhadap Orang dengan HIV/AIDS (ODHA) dalam upaya menghilangkan diskriminasi terhadap ODHA. Program dilaksanakan dengan metode community intervention melalui kegiatan penyuluhan mengenai HIV/AIDS dan pembentukan tim Warga Peduli AIDS. Program ini memiliki tujuan untuk meningkatkan pengetahuan dan pemahaman keluarga mengenai stigma dan diskriminasi; meningkatkan pengetahuan dan pemahaman masyarakat mengenai HIV/AIDS, cara penularan, gejala, pengobatan, cara pencegahan HIV; meningkatkan kepedulian masyarakat terhadap ODHA melalui pembentukan tim warga peduli AIDS; serta mengurangi penghinaan verbal, penghindaran, pengucilan dan kekerasan fisik yang dilakukan keluarga dan masyarakat terhadap ODHA

Berdasarkan program yang diajukan oleh peneliti, maka peneliti memberikan saran sebagai berikut.

1. Yayasan Sehat Panghuripan Sukowati Kabupaten Sragen 
a. Perlu memberikan dukungan semangat kinerja kepada panitia pelaksana sehingga program dapat berjalan dengan maksimal.

b. Berperan secara aktif dalam mengajak sasaran program untuk berpartisipasi dalam mengikuti program yang akan dilaksanakan dengan cara membantu dalam penyebaran poster dan baliho di titiktitik yang telah ditentukan serta berkoordinasi dengan pendamping ODHA pada setiap kecamatan untuk mengingatkan kepada seluruh sasaran pentingnya program.

c. Dapat melaksanakan program yang diajukan sebagai program tahunan sebagai upaya meningkatkan kepedulian keluarga dan masyarakat guna menghilangkan diskriminasi terhadap ODHA.

d. Membuat program penguatan diri ODHA yang mengalami perlakuan diskriminasi.

2. Pemerintah Daerah Kabupaten Sragen a. Memberikan bantuan untuk perijizan mengenai kegiatan yang akan dilaksanakan demi kelancaran pelaksanaan program agar tercapai apa yang menjadi tujuan program

b. Ikut serta dalam mengawasi dan mengevaluasi pelaksanaan program.

c. Membuat regulasi kebijakan mengenai hukuman bagi tindakan diskriminasi terhadap ODHA di Kabupaten Sragen

d. Memberikan dukungan dana dalam program peningkatan kepedulian keluarga dan masyarakat terhadap Orang dengan HIV/AIDS (ODHA) dalam upaya menghilangkan diskriminasi terhadap ODHA.

e. Menyusun buku paduan pembentukan WPA tingkat desa/kelurahan dan merealisasikan secara bertahap kepada seluruh desa/kelurahan di Kabupaten Sragen.

f. Mengeluarkan Surat Keterangan mengenai pembentukan WPA di setiap kecamatan.

\section{DAFTAR PUSTAKA}


Achmad Wisnu Maarif. 2017. Diskriminasi Orang dengan HIV/AIDS (ODHA) "Study kasus Kelompok Dukungan Sebaya (KDS) Smile Plus Temanggung”. Skripsi dari Universitas Islam Negeri Sunan Kalijaga Yogyakarta.

Bambang Rustanto.(2014). Diskriminasi. Retrieved 05 August, 2019, from http://bambangrustanto.blogspot.com/2014/04/diskrimin asi.html

Dian Afriani, dkk.(2018). Diskriminasi Dalam Novel Aku Manusia, Kamu Bukan Tuhan Karya Bhina Wiriadinata. STKIP PGRI Sumatera Barat.

Dwi Heru Sukoco. 1991. Profesi Pekerjaan Sosial. Bandung : Kopma STKS.

Femita Adelina, dkk.(2017,April). Jurnal Sains Psikologi. Hubungan Antara Prasangka Sosial dan Intensi Melakukan Diskriminasi Mahasiswa Etnis Jawa terhadap Mahasiswa yang Berasal dari Nusa Tenggara Timur,6(1),1-8.

Kementrian Kesehatan RI.(2019).Laporan Perkembangan HIV AIDS \& Penyakit Infeksi Menular Seksual (PIMS) di Indonesia Triwulan I Tahun 2019. Retrieved 10 August, 2019, from http://siha.depkes.go.id/portal/perkemban gan-kasus-HIV/AIDS_pims

Kementrian Sosial RI. 2005. Pedoman Upaya Menghilangkan Stigma dan Diskriminasi HIV/AIDS. Jakarta.

KPA Strategi Nasional Penanggulangan HIV dan AIDS. Retrieved 10 August, 2019, from http://kebijakanaidsindonesia.net

\section{Program}

Intervensi Terpadu bagi Orang dengan HIV/AIDS (ODHA) Penyandang Masalah Kesejahteraan Sosial (PMKS). Jakarta.

Lina Favourita Sutiaputri.2014. Dasar-dasar Pengetahuan HIV/AIDS. Dalam Lina Favourita (Ed.). Modul Praktik Pekerjaan Sosial dengan HIV/AIDS. Bandung:
Pusat Kajian dan Layanan HIV/AIDS STKS Bandung.

Okezone.com. Diakses pada tanggal 30 Mei 2020 dari https://news.okezone.com/amp/2013/06/2 7/521/828722/bocah-odha-yang-didugasengaja-dibuang-kini-bernama-meila

Sugiyono. 2015. Metode Penelitian: Kualitatif, Kuantitatif, dan $R$ \& $D$. Bandung : Alfabeta.

Tribun Jateng. Diakses pada tanggal 10 September 2019 dari https:///jateng.tribunnews.com/amp/2018/ 11/22/jumlah-penderita-hiv-aids-dijateng-duduki-peringkat-keempatnasional-setelah-papua

Umi Salamah. 2012. Diskriminasi terhadap Orang dengan HIV/AIDS di Kota Pangkalpinang Provinsi Kepulauan Bangka Belitung. Skripsi dari Sekolah Tinggi Kesejahteraan Sosial Bandung.

UNAIDS. (2005, April). HIV - Related Stigma, Discrimination and Human Rights Violations. Case studies of successful programmes. UNAIDS, Geneva.

Undang-undang Nomor 39 Tahun 1999 tentang Hak Asasi Manusia

Yayasan Sehat Panghuripan Sukowati. 2020. Profil Yayasan Sehat Panghuripan Sukowati Kabupaten Sragen. Sragen: arsip yayasan. 